\title{
KARAKTERISTIK, KEMISKINAN, GENDER DAN PERSEPSI PENCARI MASOI (Cryptocarya massoia (Oken) Kosterm.) (Studi Kasus di Kabupaten Teluk Wondama, Provinsi Papua Barat)
}

\author{
(Characteristics, Poverty, Gender and Perceptions of \\ Masoi's (Cryptocarya massoia (Oken) Kosterm.) Collectors \\ (A Case Study in Teluk Wondama Regency, West Papua Province))
}

\author{
Baharinawati W. Hastanti ${ }^{1} \&$ Julanda Noya ${ }^{2}$ \\ ${ }^{1}$ Peneliti pada Balai Penelitian dan Pengembangan Teknologi Pengelolaan DAS Surakarta \\ Jl. Ahmad Yani Kotak Pos 295 Pabelan Kartosura - Surakarta \\ Telp (0271) 716709, Fax (0271) 716959 \\ ${ }^{2}$ Teknisi Litkayasa pada Balai Penelitian dan Pengembangan LHK Manokwari \\ Jl. Inamberi - Susweni Kotak Pos 159 Manokwari 98313 \\ Telp (0986) 213437, Fax (0986) 213441 \\ Email :baharinawati@gmail.com
}

\begin{abstract}
S
Masoi is one of the most important NTFP from Papua. Results of the refining are the manufacture of perfumes, cosmetics, aromatherapy and basic materials maker flavour of food. This plant grows naturally in Fakfak, Kaimana, Teluk Wondama, Nabire, Jayapura, Sarmi, and Merauke. In general, masoi's collector is a side job for people surrounding forests. The purpose of this study was to describe of socioecomics characteristic, poverty, gender and community perceptions of masoi collectors in Teluk Wondama. This study used quantitative with support of qualitative approach. The method of this research was survey which used questionnaires. Characteristics of masoi's collectors are man, at productive age, less-educated, family status that is high in the number of dependents family and low income. Based on the number of dependents family and low income, masoi's collectors are classified as "living in poverty". Gender is observed in the role of woman in the group of masoi's collectors. Perceptions of masoi's collectors of masoi's plant are positive as it is generally assumed as a high economic and high benefit plant. Although this plant is suitable for cultivation, masoi's collectors are not interested in masoi's cultivation. It is mainly because of 1) difficulties to acquire massoi's seedlings, 2) perseverance and accuracy requirements for cultivation, 3) high failure of cultivation, 4) long harvest period, 5) the unavailability of sustainable and environmentally friendly technology for masoi's harvesting.
\end{abstract}

Keywords: Characteristics, poverty, gender, perceptions

\begin{abstract}
ABSTRAK
Masoi adalah salah satu HHBK andalan Papua. Hasil penyulingannya merupakan bahan dasar pembuatan parfum, kosmetika, aromaterapi dan bahan dasar pembuat aroma makanan. Tanaman ini tumbuh menyebar secara alami dari Fakfak, Kaimana, Teluk Wondama, Nabire, Jayapura, Sarmi hingga Merauke. Tujuan penelitian ini adalah menggambarkan karakteristik sosial ekonomi, kemiskinan, gender dan persepsi komunitas pencari masoi di Kabupaten Teluk Wondama. Pendekatan penelitian ini menggunakan pendekatan kuantitatif dengan dukungan pendekatan kualitatif. Metode penelitian ini adalah survei menggunakan kuesioner. Pencarian masoi dilakukan sebagai pekerjaan sampingan masyarakat sekitar hutan. Karakteristik masyarakat pencari masoi antara lain berjenis kelamin laki-laki, pada usia produktif, berpendidikan rendah, status berkeluarga dengan tanggungan keluarga yang banyak dan tingkat pendapatan yang rendah. Berdasarkan banyaknya tanggungan anggota keluarga dan pendapatan yang rendah, pencari masoi dikategorikan hidup dalam kemiskinan. Gender terlihat pada peranan dan posisi perempuan di kelompok pencari masoi. Persepsi pencari masoi terhadap tanaman masoi pada umumnya positif, karena dianggap
\end{abstract}


bernilai ekonomi tinggi dan kaya akan manfaat. Namun kurang tertarik untuk menanam walaupun secara umum masoi cocok ditanam di daerah tersebut dan masih luasnya lahan yang bisa dikelola dengan masoi. Hal tersebut dikarenakan 1) sulitnya memperoleh bibit masoi, 2) perlu ketekunan dan ketelitian dalam penanaman masoi, 3) tingkat kegagalan tanaman tinggi, 4) memerlukan waktu yang lama untuk memperoleh hasilnya, 5) belum diperoleh teknik pemanenan yang ramah lingkungan dan berasas kelestarian.

Kata kunci : Karakteristik, kemiskinan, gender, persepsi

\section{PENDAHULUAN}

Masoi (Cryptocarya massoia (Oken) Kosterm) adalah salah satu Hasil Hutan Bukan Kayu (HHBK) andalan Papua. Tanaman sekerabat kayu manis ini, kulitnya mempunyai nilai ekonomi tinggi. Hasil penyulingannya merupakan bahan dasar pembuatan parfum, kosmetika, aromaterapi dan bahan dasar pembuat aroma makanan. Populasi Masoi di Papua berada di wilayah Kabupaten Nabire, Kaimana, Fak-fak, Merauke, Jayapura, Sarmi, dan Manokwari (Kuswandi, 2015).

Masoi sudah diperdagangkan di Papua sejak abad 14, ketika para pedagang dari penjuru Nusantara tertarik datang ke wilayah Papua bagian Barat Daya untuk mencari jenis kayu ini. Komoditas kayu yang sebelumnya oleh masyarakat di Papua dikenal sebagai aikor atau aikori mulai diperkenalkan oleh para pedagang dengan nama mesoyi atau masoi (Mahmud, 2014).

Sama dengan pencarian gaharu, pencarian masoi merupakan salah satu alternatif mata pencaharian bagi sebagian masyarakat Papua di sekitar kawasan hutan. Pekerjaan mencari masoi dilakukan sebagai usaha sampingan masyarakat selain mata pencaharian utama (Diarto, et al., 2012). Pencarian masoi biasa dilakukan pada bulanbulan tertentu ketika masyarakat membutuhkan dana tambahan untuk keperluan pesta adat, pernikahan, biaya sekolah dan perayaan keagamaan seperti Natal dan Tahun Baru.

Pada umumnya masoi tumbuh di daerah berbukit-bukit dan bergunung-gunung, semakin berkurangnya jenis ini memaksa para pencari masoi masuk semakin jauh ke hutan, sehingga membutuhkan waktu berhari-hari sampai berminggu-minggu. Pencarian masoi dilakukan secara berkelompok dengan pembagian tugas pada masing-masing individu sesuai dengan kemampuannya. Pendapatan yang diperoleh biasanya dibagi secara merata sesuai dengan hasil yang diperoleh.

Harga minyak masoi di pasar dalam negeri bisa mencapai $\mathrm{Rp} 2.000 .000,-/$ liter, sedang harga pasar dunia antara $\$ 250-350 / \mathrm{kg}$ tergantung tingginya kadar lactone (Kuswandi, 2015). Nilai ekonomi kulit masoi yang terbilang tinggi merupakan daya tarik walaupun bukan menjadi alternatif pekerjaan sampingan bagi para pencari masoi. Pada umumnya pengambilan kulit masoi dilakukan dengan cara menebang pohon secara destruktif sehingga merupakan ancaman bagi keberlangsungan jenis ini. Sampai sekarang belum ada teknologi pemanenan masoi yang bisa mendukung kelestarian jenis dan meningkatkan produktivitas masoi.

Untuk peningkatan produktivitas tanaman masoi diperlukan informasi tentang karakteristik sosial dan ekonomi (Husaini, 2012) komunitas pencari masoi agar dapat diperoleh pemahaman yang komprehensif tentang latar belakang pemanfaatan masoi untuk pengembangan masoi sebagai salah satu HHBK andalan setempat.

Tujuan penelitian ini adalah untuk menggambarkan karakteristik sosial ekonomi, 
kemiskinan, gender dan persepsi komunitas pencari masoi di Kabupaten Teluk Wondama.

\section{METODE PENELITIAN}

\section{A. Lokasi dan Waktu Penelitian}

Penelitian dilakukan di wilayah Kabupaten Teluk Wondama pada bulan September 2015. Kabupaten Teluk Wondama merupakan salah satu penghasil kulit masoi di Provinsi Papua Barat. Kabupaten Teluk Wondama terletak pada kordinat $0^{0} 15^{\prime \prime}$ $3^{0} 25^{\prime}$ LS dan $132^{0} 35^{\prime \prime}-134^{0} 45^{\prime}$ BT. Di bawah ini adalah peta Kabupaten Teluk Wondama.

\section{B. Alat dan Bahan}

Alat dan bahan penelitian yang digunakan adalah tally sheet, alat tulis menulis, recorder dan kamera.

\section{Metode Penelitian}

Pendekatan penelitian ini menggunakan pendekatan kuantitatif dengan dukungan pendekatan kualitatif. Metode penelitian ini adalah survei menggunakan kuesioner (Adalina, 2017).

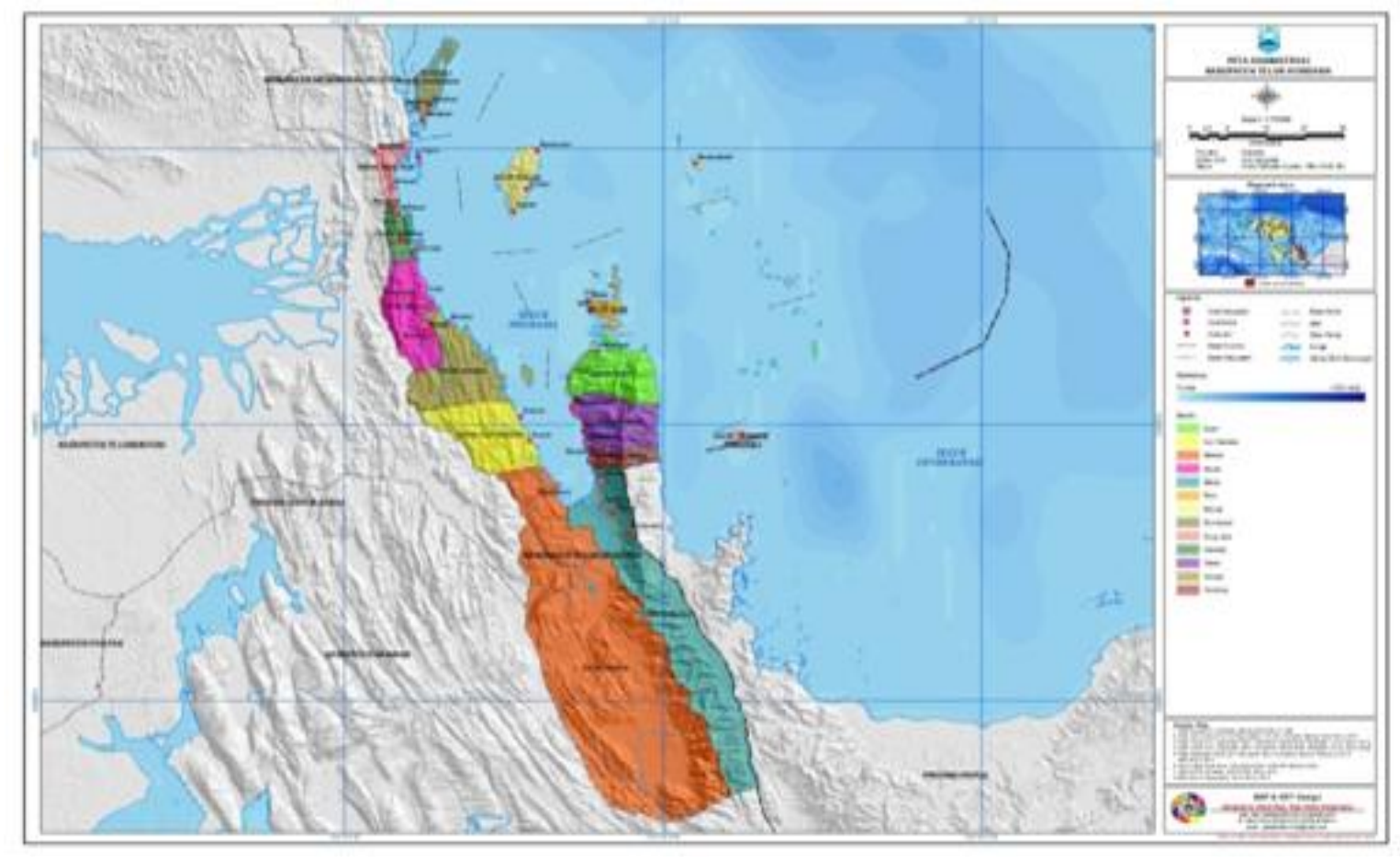

Gambar 1. Peta Kabupaten Teluk Wondama

Figure 1.Map of Teluk Wondama Regency

Sumber : Peta Tematik Indonesia

Source : Indonesia thematic maps

\section{Teknik pengumpulan data}

Jenis data yang dikumpulkan dalam penelitian terdiri dari data primer dan data sekunder yang diuraikan sebagai berikut:
Data primer

Data primer diperoleh dari hasil wawancara dan kuisioner serta dari hasil observasi responden di lapangan (Adalina, 2017). Jumlah pencari masoi yang dijadikan 
sebagai responden sebanyak 60 orang yang terdiri dari 30 orang dari Kampung Senderawoi dan 30 orang dari Kampung Rado. Pemilihan responden dilakukan secara purposif (Sanudin \& Fauziyah, 2015), dengan kriteria terlibat dalam kelompok pencari masoi. Selain responden dari pencari masoi, wawancara mendalam (indepth interview) juga dilakukan terhadap informan kunci (Diniyati \& Awang, 2010) atau orangorang yang lebih memahami dan mengetahui tentang kemiskinan, gender dan pembagian kerja pencari masoi serta persepsi tanaman masoi yang terdiri dari tokoh masyarakat, kepala suku, pedagang pengumpul, Kepala dan Petugas Dinas Kehutanan Kabupaten Teluk Wondama.

\section{Data sekunder}

Data sekunder sifatnya sebagai data pendukung dan penunjang untuk melengkapi data primer (Supratman, 2008). Data ini diperoleh melalui observasi ataupun studi pustaka. Data sekunder yang dikumpulkan adalah kondisi geografis, demografi keadaan ekonomi masyarakat dan kajian ataupun penelitian terkait tanaman masoi.

\section{Teknik analisis data}

Data yang dikumpulkan dianalisis secara deskriptif kuantitatif dan kualitatif (Kadir, et al, 2012). Analisis deskriptif kuantitatif digunakan untuk mendapatkan penjelasan mengenai karakteristik sosial dan ekonomi pencari masoi. Analisis deskriptif kualitatif digunakan untuk mendapatkan penjelasan mengenai kemiskinan pencari masoi, gender dalam pembagian kerja pencari masoi dan persepsi para pencari masoi terhadap tanaman masoi.

\section{HASIL DAN PEMBAHASAN}

\section{A. Karakteristik Sosial dan Ekonomi Pencari Masoi}

Para pencari masoi di Kabupaten Teluk Wondama memiliki karakteristik sosial ekonomi tertentu karena kegiatan pencarian masoi memerlukan syarat-syarat khusus dan adanya motivasi ekonomi (Nurdina, et al., 2015) masing-masing individu pencari masoi. Pencarian masoi di Teluk Wondama dilakukan secara berkelompok terdiri dari 7 hingga 15 orang. Setiap orang dalam kelompok memiliki tanggung jawab dan tugas yang jelas seperti bagian survey, menebang, menguliti, menjemur, mengangkut dan memasak.

Berdasarkan kriteria persyaratan tertentu dalam pencarian masoi dan motivasinya maka karakteristik sosial ekonomi pencari masoi terdiri dari: 1) Jenis kelamin, 2) Umur, 3) Tingkat pendidikan, 4) Pekerjaaan utama, 5) Status perkawinan dan Jumlah tanggungan keluarga, 6) Tingkat pendapatan.

\section{Jenis kelamin}

Pola pertumbuhan tanaman masoi di alam berkelompok dan tiap kelompok tersebar secara sporadis di hutan belukar. Jenis ini biasa berasosiasi dengan tumbuhan lain. Secara alami masoi tumbuh pada hutan dataran rendah dengan ketinggian $10-700$ mdpl (Rostiwati \& Martono, 2014). Di Teluk Wondama, masoi tumbuh pada ketinggian 900 mdpl pada areal hutan alam. Kondisi tempat tumbuh yang berada di hutan menyebabkan sebagian besar para pencari masoi berjenis kelamin laki-laki (Saidah, 2013).

Pekerjaaan pencarian masoi memerlukan ketahanan fisik yang baik karena harus menempuh perjalanan jauh dengan medan bergunung-gunung, terjal dan curam. Lebih jauh lagi masoi saat ini semakin susah ditemukan sehingga harus masuk jauh ke dalam hutan. Pencari masoi dilakukan oleh kepala keluarga (laki-laki), karena mereka memerlukan tambahan 
penghasilan bagi keluarganya. Di bawah ini tersaji Tabel 1 jenis kelamin responden.

Tabel 1 menunjukkan bahwa pekerjaan mencari masoi didominasi laki-laki. Hal ini dikarenakan adanya pembagian kerja menurut jenis kelamin yang telah menjadi kesepakatan masyarakat awam terhadap laki-laki dan perempuan. Dari situ kemudian muncul nilainilai dan norma yang berbeda untuk laki-laki dan perempuan baik dalam keluarga dan lembaga masyarakat (Nurlian \& Daulay, 2008).

\section{Umur}

Sebagian besar pencari masoi merupakan tenaga kerja dengan usia produktif yaitu kelompok usia pada rentang umur 15 - 64 tahun (Statistik, 2008). Usia produktif dianggap usia yang matang untuk menghasilkan barang atau jasa baik dari aspek fisik maupun mental. Sebagian besar pencari masoi berusia produktif antara 15 - 35 tahun seperti dijelaskan pada Tabel 2.

Tabel 1. Jenis kelamin responden

Table 1.Gender of responden

\begin{tabular}{lcc}
\hline $\begin{array}{l}\text { Jenis Kelamin } \\
\text { Sex }\end{array}$ & $\begin{array}{c}\text { Jumlah (orang) } \\
\text { Amount (peope) }\end{array}$ & $\begin{array}{c}\text { Persentase (\%) } \\
\text { Percentage (\%) }\end{array}$ \\
\hline Laki-laki (Male) & 56 & 93,333 \\
Perempuan (Female) & 4 & 6,667 \\
\hline Total & 60 & 100,000 \\
Total & & \\
\hline
\end{tabular}

Sumber : Data primer, 2015

Source : Primary data, 2015

Tabel 2. Umur responden

Table 2. Age of respondent

\begin{tabular}{lcc}
\hline $\begin{array}{l}\text { Kisaran umur (tahun) } \\
\text { Range of age (year) }\end{array}$ & $\begin{array}{c}\text { Jumlah responden (orang) } \\
\text { Number of respondent (people) }\end{array}$ & $\begin{array}{c}\text { Persentase (\%) } \\
\text { Precentage (\%) }\end{array}$ \\
\hline$<14$ & 2 & 3,333 \\
$15-20$ & 10 & 16,667 \\
$21-25$ & 16 & 26,667 \\
$26-30$ & 12 & 12,000 \\
$31-35$ & 14 & 23,333 \\
$36-40$ & 2 & 3,333 \\
$41-45$ & 2 & 3,333 \\
$46-50$ & 2 & 3,333 \\
$50<$ & 0 & 0 \\
\hline Total & 60 & 100,000 \\
Total & & \\
\hline
\end{tabular}

Sumber : Data primer, 2015

Source : Primary data, 2015

Pekerjaan mencari masoi merupakan pekerjaan yang memerlukan fisik yang kuat. Produktivitas kerja para pencari masoi juga dipengaruhi oleh umur (Achmad, et al, 2015). Umur tenaga kerja menentukan keberhasilan dalam melakukan suatu 
pekerjaan baik fisik ataupun non fisik. Terdapat batasan umur tertentu seseorang yang dapat bekerja. Ada pula yang semakin tua semakin tidak bekerja karena memasuki masa pensiun (A.Kurniawan, 2015).

\section{Tingkat pendidikan}

Pekerjaan pencarian masoi umumnya tidak memerlukan pendidikan formal namun memerlukan keterampilan tertentu seperti mengenal jenis masoi, menebang dan menguliti pohon. Tingkat pendidikan dalam pekerjaan pencarian masoi tidak berpengaruh terhadap perolehan masoi yang maksimal karena perolehan masoi dengan jumlah yang banyak hanya dapat dicapai dengan kekuatan fisik para pencari untuk mencapai tempat yang jauh. Semakin jauh tempat yang dicapai dalam perjalanan pencarian masoi maka akan menentukan semakin banyak hasil yang diperoleh. Sebagian besar para pencari masoi berpendidikan SD dan SMP. Seperti dijelaskan pada Tabel 3.

Tabel 3. Tingkat pendidikan

Table 3. Level of education

\begin{tabular}{lcc}
\hline \multicolumn{1}{c}{$\begin{array}{c}\text { Tingkat pendidikan } \\
\text { Level of education }\end{array}$} & $\begin{array}{c}\text { Jumlah responden (orang) } \\
\text { Number of respondent }\end{array}$ & $\begin{array}{c}\text { Presentase (\%) } \\
\text { Percentage (\%) }\end{array}$ \\
\hline $\begin{array}{l}\text { Tidak Sekolah } \\
\text { No School }\end{array}$ & 8 & 13,333 \\
$\begin{array}{l}\text { SD (Sekolah Dasar) } \\
\text { Elementary school }\end{array}$ & 27 & 45,000 \\
$\begin{array}{l}\text { SMP (Sekolah Menengah Pertama) } \\
\text { Yunior High School }\end{array}$ & 22 & 36,667 \\
$\begin{array}{l}\text { SMA (Sekolah Menengah Atas) } \\
\text { Senior High School }\end{array}$ & & 05,000 \\
$\begin{array}{l}\text { PT (Perguruan Tinggi) } \\
\text { College }\end{array}$ & 3 & 0 \\
\hline $\begin{array}{l}\text { Total } \\
\text { Total }\end{array}$ & 0 & 100,000 \\
\hline
\end{tabular}

Sumber : Data primer, 2015

Source : Primary data, 2015

Tingkat pendidikan responden pencari masoi sebagian besar tergolong rendah karena pekerjaan mencari masoi memang tidak memerlukan pendidikan formal yang tinggi tapi justru memerlukan keterampilan yang tidak diperoleh dari pendidikan formal. Oleh karenanya pekerjaan ini termasuk dalam sektor informal yang menjadi salah satu pilihan penduduk untuk menambah penghasilan.

Ada beberapa fenomena pendidikan di daerah pedesaan, seperti juga yang terjadi di Teluk Wondama, yang menyebabkan rendahnya tingkat pendidikan masyarakat. Diantaranya adalah: 1) tingginya jumlah anak-anak yang putus sekolah maupun tidak bersekolah karena alasan ekonomi, 2) terbatasnya jumlah anak-anak dari pedesaan yang berhasil masuk sekolah lanjutan menengah, dan 3) sedikitnya jumlah anakanak yang berhasil melanjutkan pendidikan ke jenjang perguruan tinggi setelah selesai 
menyelesaikan pendidikan di sekolah lanjutan menengah (Todaro, 2008).

\section{Pekerjaan utama}

Sama halnya dengan masyarakat di Papua, sebagian besar penduduk di Teluk Wondama bermata pencaharian sebagai petani/berkebun dengan sistem perladangan berpindah (shifting cultivation) (Talaohu, 2013). Praktek perladangan di Papua masih sangat sederhana mulai dari pertanian meramu, ladang berpindah serta sebagian sudah petani ladang menetap dan perkebunan. Ada beberapa alasan penyebab praktek peladangan berpindah di Papua antara lain : 1) masih terlalu luasnya lahan dan kurangnya penduduk, 2) status pemilikan lahan bukan milik individu tetapi milik komunal atau ulayat, 3) masih rendahnya pendidikan dan keterampilan petani dan 4) sikap petani yang mau menerima apa adanya dari alam (fatalistic) (Konro et al., 2002). Pencarian masoi dilakukan ketika masa bera (fallow period) (Beja, et al, 2015). Sebagian besar pencari masoi bermata pencaharian sebagai petani.

Tabel 4. Pekerjaan utama responden

Table 4. Main ocupation respondent

\begin{tabular}{lcc}
\hline \multicolumn{1}{c}{$\begin{array}{c}\text { Jenis Mata Pencaharian } \\
\text { Livelihoods }\end{array}$} & $\begin{array}{c}\text { Jumlah Responden (orang) } \\
\text { Number of respondent (people) }\end{array}$ & $\begin{array}{c}\text { Persentase (\%) } \\
\text { Percentage (\%) }\end{array}$ \\
\hline $\begin{array}{l}\text { Petani/Pekebun } \\
\text { Farmer/gardener }\end{array}$ & 31 & 51,667 \\
$\begin{array}{l}\text { Nelayan } \\
\text { Fisherman }\end{array}$ & 11 & 18,333 \\
$\begin{array}{l}\text { Pedagang } \\
\text { trader }\end{array}$ & 2 & 3,333 \\
$\begin{array}{l}\text { Swasta } \\
\text { entepreneur }\end{array}$ & 2 & 3,333 \\
$\begin{array}{l}\text { Lain-lain } \\
\text { etc }\end{array}$ & 4 & 6,667 \\
\hline Total & 4 & 100,000 \\
Total & 60 & \\
\hline
\end{tabular}

Sumber : Data primer, 2015

Source : Primary data, 2015

Tabel 4 menjelaskan bahwa selain petani/pekebun, pekerjaan utama para pencari masoi adalah nelayan. Wilayah Teluk Wondama sebagian besar dikeliling laut karena terletak diantara dua teluk, yaitu Teluk Cenderawasih dan Teluk Bintuni. Oleh karenanya sebagian besar penduduk juga menggantungkan kehidupannya dari laut dan hasil-hasilnya.

Masyarakat pesisir Indonesia sebagian besar bermatapencaharian sebagai nelayan. Pekerjaan nelayan telah dilakukan secara turun-temurun dari nenek moyang. Karakteristik masyarakat nelayan terbentuk mengikuti sifat dinamis sumber daya alam, sehingga untuk mendapatkan hasil tangkapan yang maksimal, nelayan harus berpindahpindah. Selain itu resiko pekerjaan yang tinggi menyebabkan nelayan hidup dalam suasana alam yang keras yang selalu 
diliputi ketidakpastian dalam menjalankan pekerjaannya (Wasak, 2012).

Untuk menghadapi resiko fluktuasi harga ikan dan resiko cuaca, beberapa nelayan di Teluk Wondama melalukan diversifikasi pekerjaan dengan ikut dalam kelompok pencari masoi di hutan. Diversifikasi mata pencaharian merupakan atribut yang penting bagi masyarakat pedesaan di negara-negara yang berkembang (Helmi, et al., 2012). Diversifikasi sumber pendapatan merupakan pilihan yang rasional di tengah tingginya resiko nelayan menghadapi fluktuasi harga ikan dan cuaca yang tidak menentu.

\section{Status perkawinan dan jumlah tanggungan anggota keluarga}

Berdasarkan tabel status perkawinan pencari masoi, jumlah pencari masoi yang sudah berkeluarga lebih banyak dibanding dengan pencari masoi yang berstatus bujang. Hal ini dikarenakan pencari masoi yang berkeluarga harus mencari tambahan penghasilan ekstra untuk mencukupi kebutuhan keluarganya. Sebagian besar responden pencari masoi berstatus menikah seperti dipaparkan.

Tabel 5. Status perkawinan responden

Table 5. Marital status of respondent

\begin{tabular}{lcc}
\hline \multicolumn{1}{c}{$\begin{array}{c}\text { Status perkawinan } \\
\text { Marital status }\end{array}$} & $\begin{array}{c}\text { Jumlah responden (orang) } \\
\text { Number of respondent (people) }\end{array}$ & $\begin{array}{c}\text { Persentase (\%) } \\
\text { Percentage (\%) }\end{array}$ \\
\hline $\begin{array}{l}\text { Menikah } \\
\text { Married } \\
\text { Tidak/Belum Menikah }\end{array}$ & 43 & 71,667 \\
Singe & 17 & 28,333 \\
\hline $\begin{array}{l}\text { Total } \\
\text { Total }\end{array}$ & 60 & 100,000 \\
\hline
\end{tabular}

Sumber : Data primer, 2015

Source : Primary data, 2015

Para pencari masoi sebagian besar berstatus menikah, sebagai seorang kepala keluarga, pencari masoi harus bertanggung jawab untuk menghidupi anggota keluarganya. Pencarian masoi dilakukan untuk menambah penghasilan dalam rangka mencukupi kebutuhan rumah tangga.

Sebagian besar pencari masoi memiliki tanggungan lebih dari 5 orang dalam keluarganya. Oleh karenanya harus mencari tambahan penghasilan agar bisa mencukupi kebutuhan hidup keluarganya. Terlebih sebagian masyarakat di Papua hidup dalam sistem keluarga luas/besar (extended family) dalam kehidupan sehari-harinya. Keluarga luas adalah ikatan kekeluargaan yang terdiri dari beberapa keluarga inti seperti suami, istri, anak-anak, ayah, ibu, kakek, nenek, paman, bibi, sepupu dan keponakan-keponakan. Sehingga sudah menjadi konsekuensi bahwa beban yang harus ditanggung oleh seorang kepala keluarga di Papua untuk menafkahi anggota keluarganya menjadi begitu besar.

Banyaknya anggota keluarga yang harus ditanggung oleh seorang kepala keluarga menjadikan harus memutar otak untuk menambah penghasilannya, misalnya dengan mencari masoi. Berdasarkan data 
dependency ratio tahun 2013 Kabupaten Teluk Wondama menunjukkan angka 63,55\%, yang berarti setiap 100 penduduk usia produktif menanggung 63 orang penduduk usia tidak produktif, atau 1 orang usia produktif menanggung 6 orang usia tidak produktif. Hal ini menunjukkan betapa beratnya beban kepala keluarga di Kabupaten Teluk Wondama (Wondama, 2013).

Tabel 6. Jumlah tanggungan anggota keluarga

Table 6. Number of dependens

\begin{tabular}{lcc}
\hline $\begin{array}{c}\text { Tanggungan keluarga (orang) } \\
\text { Dependents (people) }\end{array}$ & $\begin{array}{c}\text { Jumlah responden (orang) } \\
\text { Number of responden (people) }\end{array}$ & $\begin{array}{c}\text { Persentase (\%) } \\
\text { Percentage (\%) }\end{array}$ \\
\hline $0-5$ & 8 & 13,333 \\
$6-10$ & 12 & 20,000 \\
$11-15$ & 18 & 30,000 \\
$16-20$ & 21 & 35,000 \\
$20<$ & 1 & 1,667 \\
\hline Total & 60 & 100,00 \\
Total & & \\
\hline
\end{tabular}

Sumber : Data primer, 2015

Source : Primary data, 2015

Tabel 6 menyebutkan bahwa beban tanggungan yang dimiliki oleh pencari masoi sebagian besar berada di atas 5 orang. Sehingga dapat dibayangkan betapa beratnya beban para pencari masoi untuk memenuhi kebutuhan hidup anggota keluarganya.

\section{Tingkat pendapatan}

Penyebab utama kemiskinan suatu rumah tangga adalah rendahnya pendapatan yang mereka terima. Sedangkan karakteristik penduduk miskin tersebut antara lain memiliki rata-rata jumlah tanggungan keluarga yang banyak. Jumlah anggota keluarga yang banyak merupakan salah satu indikasi yang dominan dalam menentukan tingkat kemiskinan rumah tangga. Semakin besar tanggungan keluarga, semakin besar jumlah konsumsi berasnya, sehingga kemiskinan semakin tinggi. Namun penyebab kemiskinan tidaklah sama untuk setiap kondisi (Maulana, 2013).
Dalam mencari masoi, pencari masoi dapat meninggalkan keluarganya selama dua minggu sampai satu bulan untuk masuk ke dalam hutan. Dalam satu periode pencarian masoi, hasil yang diperoleh mencapai $300 \mathrm{~kg}$ sampai 1 ton tergantung banyaknya pohon masoi yang bisa ditemukan. Namun sekarang masoi di Teluk Wondama sudah mulai langka, sehingga perolehan kulit masoi yang diperoleh juga semakin menurun. Sebagai gambaran, kulit masoi dijual kepada para pedagang $\mathrm{Rp}$ 45.000/kg. Dalam satu kali keluar hutan, kelompok ini membawa sekitar $300 \mathrm{~kg}$ kulit masoi, seharga 300 x $45.000=13.500 .000$ yang akan dikurangi dengan biaya makan, transportasi dan kontribusi pada pemilik ulayat. Apabila diasumsikan biaya makan Rp 2.000.000 dan biaya transportasi Rp 2.000 .000 serta kontribusi adat Rp 5.000/kg, maka jumlah bersih yang diperoleh adalah 
Rp 7.500.000 yang akan dibagi rata kepada anggota kelompok yang terdiri dari $7-10$ orang.

Tingkat pendapatan rumah tangga pencari masoi dapat menunjukkan kondisi ekonomi, termasuk dalam katagori miskin atau tidak. Pendapatan dan jumlah tanggungan keluarga merupakan salah satu indikator untuk mengetahui miskin dan tidaknya seseorang.

Tabel 7. Tingkat pendapatan responden

Table 7. Level of responden salaries

\begin{tabular}{lcc}
\hline $\begin{array}{c}\text { Pendapatan utama (Rp/bulan) } \\
\text { Main salaries (Rp/month) }\end{array}$ & $\begin{array}{c}\text { Jumlah responden (orang) } \\
\text { Number of respondents (people) }\end{array}$ & $\begin{array}{c}\text { Persentase (\%) } \\
\text { Percentage (\%) }\end{array}$ \\
\hline$<500.000$ & 1 & 1,67 \\
$500.000-1.000 .000$ & 12 & 20,00 \\
$1.000 .000-1.500 .000$ & 16 & 26,67 \\
$1.500 .000-2.000 .000$ & 23 & 38,33 \\
$2.500 .000-3.000 .000$ & 7 & 11,67 \\
$3.500 .000-4.000 .000$ & 1 & 1,67 \\
$4.000 .000<$ & 0 & 0 \\
\hline Total & $\mathbf{6 0}$ & $\mathbf{1 0 0 , 0 0}$ \\
\hline
\end{tabular}

Sumber : Data primer, 2015

Source : Primary Data, 2015

Tabel 7 menunjukkan bahwa tingkat pendapatan responden yang diperoleh per bulan, baik dari pekerjaan utama maupun pencarian masoi, apabila dianalisis dengan memperhatikan harga-harga kebutuhan yang relatif mahal di Papua dan jumlah anggota keluarga yang ditanggung, maka pencari masoi dapat dikategorikan dalam penduduk miskin. Kemiskinan diartikan sebagai kondisi ketidakcukupan pendapatan dalam memenuhi kebutuhan pokok sehingga tidak mampu untuk menjamin kelangsungan hidup (Suryawati, 2005).

\section{B. Kemiskinan Dalam Kehidupan Pencari Masoi}

Kehidupan keluarga pencari masoi tidak jauh dari anggapan tentang kemiskinan masyarakat di sekitar hutan. Penghasilan yang tidak menentu dan banyaknya anggota keluarga yang ditanggung menyebabkan susahnya seorang kepala keluarga untuk memenuhi kebutuhan sehari-hari sesuai dengan standar kehidupan layak. Oleh karena itu pencarian masoi dilakukan dengan alasan kurangnya pendapatan yang diperoleh dari pekerjaan utama yang ditekuni oleh para pencari masoi.

Kemiskinan dinyatakan sebagai suatu keadaan kekurangan harta atau benda berharga yang diderita oleh seseorang atau kelompok orang. Akibat dari kekurangan harta atau benda tersebut maka seseorang atau sekelompok orang merasa kurang mampu membiayai hidupnya sebagai mana layaknya. Kekurangmampuan tersebut mungkin hanya pada tingkat kebutuhankebutuhan budaya (adat istiadat, upacaraupacara, moral dan etika) atau pada tingkat 
pemenuhan kebutuhan sosial (pendidikan, berkomunikasi dan interaksi pada sesama) atau pada tingkat kebutuhan-kebutuhan yang mendasar (makan, minum, bertempat tinggal atau rumah, kesehatan dan sebagainya) (Asthika, 2010).

Kemiskinan pada pencari masoi tidak jauh dari budaya masyarakat setempat di Papua. Budaya untuk tinggal bersama keluarga luas (extended family) (Choi, et al., 2016) pada adat istiadat virilokal yaitu adat untuk tinggal besama dengan keluarga besar suami setelah menikah (Ari Kurniawan \& Rudiansjah, 2016). Hal ini menyebabkan seorang kepala keluarga harus memenuhi pula kebutuhan hidup seluruh anggota keluarganya, dalam hal ini adalah kebutuhan akan makanan. Adat virilokal menyebabkan seorang kepala keluarga mempunyai beban tanggungan yang berat, karena disamping harus memenuhi kebutuhan keluarga intinya, harus pula memenuhi kebutuhan hidup, orang tua maupun kerabat lain yang ikut tinggal bersama-sama.

Beberapa adat dan kebiasaan juga turut mendukung budaya kemiskinan pada masyarakat pencari masoi, diantaranya adalah pembayaran mas kawin dan dendadenda yang harus dibayar. Adat komunal pada masyarakat Papua menyebabkan ikatan yang kuat pada keluarganya (Deda \& Mofu, 2014). Solidaritas terhadap keluarga besarnya menyebabkan seseorang harus ikut menanggung biaya yang dikeluarkan keluarga ketika keluarganya mengalami kedukaan, perkawinan maupun kecelakaan atau kejadian yang tidak diinginkan.

Isolasi geografis yang terjadi di Teluk Wondama juga berdampak pada sulitnya masyarakat mendapatkan BBM, terutama jika laut sedang tidak bersahabat, pasokan
BBM akan terlambat. Ditambah lagi ulah para spekulan BBM yang turut mempermainkan kondisi kelangkaan untuk memperoleh keuntungan pribadi. Harga BBM menjadi tidak stabil sehingga mempengaruhi harga bahan pokok.

Kemiskinan yang dialami oleh para pencari masoi boleh dikatakan sebagai kemiskinan multidimensi (Syah, 2017), kemiskinan adalah bersifat multi dimensional, paling tidak terdapat 6 dimensi kemiskinan yaitu : 1) kekurangan pangan dan kelaparan, 2) ketidakberdayaan dan ketidakmampuan bicara, ketergantungan, ketidakpercayaan diri atau malu, 3) kurangnya akses terhadap infrastruktur seperti jalan, transportasi dan air bersih, 4) kerendahan pendidikan dan rendahnya kualitas pendidikan, 5) kesehatan yang lemah dan umumnya berpenyakit, 6) ketidakmampuan mengelola aset fisik, manusia, sosial dan lingkungan.

Kehidupan para pencari masoi memanglah tidak semenarik harga minyak masoi di pasaran internasional. Di tengah harga minyak masoi yang demikian melambung di pasaran ternyata tidak dinikmati oleh para pencari masoi. Harga kulit masoi dari tahun ke tahun cenderung stabil. Ketidaktahuan akan informasi harga minyak masoi menyebabkan stabilnya harga kulit masoi di tingkat pencari, sehingga tidak ada peningkatan pendapatan yang signifikan dari tahun ke tahun.

Tingkat pendidikan yang rendah dan akses informasi dan komunikasi yang rendah juga menyebabkan tidak adanya perubahan tingkat kesejahteraan pencari masoi. Kemiskinan pencari masoi dapat dijelaskan melalui capability approach (Anand et al., 2009) yang berkaitan dengan freedom of choice, pencari masoi sama sekali tidak 
memiliki freedom of choice karena terjadi capability deprivation yang mengacu pada 2 hal yaitu 1) ability to do dan, 2) ability to be. Berbagai macam deprivation yang dialami oleh komunitas pencari masoi yang sebagian besar bermata pencaharian sebagai petani dan nelayan yaitu : 1) Structural deprivation yang terkait dengan : a) power relation, pencari masoi selalu dalam posisi yang lemah sama halnya dengan pekerjaannya sebagai petani dan nelayan, b) adanya kebijakan pemerintah yang tidak mendukung penanggulangan kemiskinan, c) dualisme ekonomi yang muncul, 2) Social capability, para pencari masoi, tidak mempunyai kesempatan, informasi, pengetahuan, keterampilan dan partisipasi dalam organisasi, 3) Economic capability deprivation, pencari masoi umumnya tidak mempunyai akses dengan lembaga keuangan maupun perbankan, sehingga kebanyakan mereka terjebak pada rentenir dan lintah darat yang bermetamorfosa sebagai pengepul kulit masoi, 4) Technological deprivation, para pencari masoi tidak memiliki teknologi baru dan masih menggunakan teknologi tradisional dalam pemanenan kulit masoi, pemanenan kulit masoi masih dilakukan secara destruktif dengan menebang pohon, sehingga mendorong kelangkaan jenis ini, 5) Political capability, para pencari masoi yang sebagian besar adalah nelayan dan petani ini tidak memiliki kemampuan untuk mempengaruhi keputusan politik dan kebijakan pemerintah, tidak didengar aspirasinya serta tidak berkemampuan untuk melakukan collective action, 6) Psychological capabity, para pencari masoi yang merupakan petani dan nelayan di pedalaman Papua selalu mendapatkan stigma sebagai orang yang malas, bodoh dan tidak aspiratif. Stigma ini yang menyebabkan rendah diri dan tersepelekan dan merasa teralienisasi dari kehidupan sosial dan politik.

\section{Gender dan Pembagian Kerja Pada Komunitas Pencari Masoi}

Gender dijelaskan oleh para ilmuwan sosial sebagai perbedaan perempuan dan lakilaki yang bersifat bawaan sebagai ciptaan Tuhan dan yang bersifat bentukan budaya yang dipelajari dan disosialisasi sejak kecil (Puspitawati, 2012). Gender pada kelompok pencari masoi dapat dikaitkan pada peranan atau pembagian kerja para anggota kelompok masoi (Ahdiah, 2013). Isu-isu gender yang ada pada kelompok pencari masoi dilatarbelakangi budaya patriarki (Susanto, 2015) pada masyarakat Papua. Dalam suatu kelompok pencari masoi, perempuan tidak banyak dilibatkan dalam kegiatan tersebut. Kalau pun terlibat lebih pada peranannya sebagai tukang masak.

Posisi dan tugas tradisional perempuan di Papua masih mengurus pekerjaan domestik di dalam keluarga besarnya, dengan harapan saat keluar rumah perempuan bisa mengatasi itu dengan bekerja di luar rumah (Dwi, 2011). Akan tetapi ketika perempuan bekerja di luar rumah, pekerjaan yang ditawarkan adalah pekerjaan yang tidak beranjak dari tugastugas domestik seperti mengurus anak, memasak dan merawat orang sakit (Intan, 2014). Demikian halnya ketika perempuan ikut dalam kegiatan pencarian masoi, perempuan akan mendapatkan pekerjaan memasak sesuai dengan tugas domestiknya dalam keluarga besar.

Pembagian kerja menurut gender juga menghubungkan norma-norma dan proses sosial budaya masyarakat yang membentuk sifat maskulin dan feminim (Hartati, 2010). Peran perempuan sebagai tukang masak 
dalam kegiatan pencarian masoi dapat dikaitkan dengan stereotype gender (Zaduqisti, 2009) sebagai salah satu penghambat bagi perempuan dalam memilih pekerjaan tertentu. Pekerjaan mencari masoi memang diidentikkan dengan pekerjaan gender, sebagai tukang masak tidak banyak menuntut kekuatan fisik, namun mengandalkan keterampilan, ketelitian dan ketekunan yang identik dengan perempuan.

Sistem budaya patriarki juga menjadi salah satu sebab sistem pembagian kerja antara laki-laki dan perempuan dalam pencarian masoi. Sistem patriarki yang berlaku pada masyarakat Papua terjadi dimana kekuasaan kaum laki-laki yang mendominasi, mensubordinasi dan mendeskriminasi kaum perempuan atas badannya, seksualitasnya, pekerjaan, peranan dan statusnya baik dalam keluarga maupun masyarakat.

Pada kelompok pencari masoi dapat dikaitkan dengan keberadaan masyarakat tradisional Papua yang masih berburu dan meramu, dimana peran sosial dan ekonomi terpola pada dua bagian, yaitu pemburu untuk laki-laki dan peramu untuk kaum perempuan. Pada masyarakat seperti ini, kaum laki-laki memperoleh kesempatan lebih besar untuk memperoleh pengakuan dan prestise. Besar kecilnya hasil buruan yang diperoleh lakilaki akan menentukan kekuasaan yang diperolehnya. Semakin besar jumlah hasil buruan laki-laki maka ia semakin berkuasa. Sebaliknya semakin kecil hasil buruan yang didapat maka semakin lemah kontrol laki-laki terhadap perempuan (Rosaldo \& Lapere, 1974). Hal ini berlaku pada para pencari masoi, pencarian masoi dilakukan oleh kaum laki-laki, termasuk dalam mencari, menebang pohon, menguliti, menjemur dan mengangkut, namun ada kemungkinan kaum perempuan (yang juga memasak) membantu untuk menjemur dan mengawasi kulit masoi. Besar kecilnya hasil masoi yang diperoleh akan menentukan seberapa besar dan tingginya pengakuan dan prestise bagi laki-laki untuk menentukan kekuasaan dalam kelompok.

\section{Persepsi Terhadap Tanaman Masoi}

Persepsi didefinisikan sebagai suatu proses mengintepretasikan atau menafsirkan informasi yang diperoleh oleh sistem indera manusia. Ada tiga aspek yang relevan dengan kognisi manusia, yaitu pencatatan indera, pengenalan pola dan perhatian (Rehalat, 2014). Sedangkan faktor-faktor yang mempengaruhi persepsi individu (Arifin, et al., 2017) adalah : 1) faktor internal berupa perasaan, sikap dan kepribadian individu, prasangka, keinginan dan harapan, perhatian (fokus), proses belajar, keadaan fisik, gangguan jiwa, nilai dan kebutuhan, minat dan motivasi, 2) faktor eksternal berupa latar belakang, informasi yang diperoleh, pengetahuan dan kebutuhan sekitar dan lainlain.

Persepsi para pencari masoi terhadap tanaman masoi beragam. Namun pada dasarnya para pencari masoi menganggap masoi merupakan tanaman yang kaya manfaat dan bernilai ekonomi tinggi namun sulit untuk dibudidayakan. Bagi masyarakat di Teluk Wondama, masoi merupakan tanaman yang bernilai ekonomi tinggi karena sudah diperdagangkan sejak zaman dahulu. Permintaan kulit masoi semakin meningkat dari hari ke hari menyebabkan pencarian masoi juga semakin jauh ke hutan. Sebelumnya menurut cerita orang-orang tua di Teluk Wondama, masoi tumbuh secara alami di hutan-hutan yang dekat dengan pemukiman sehingga sangat mudah mendapatkannya. Namun sekarang tanaman 
tersebut juga semakin sulit untuk diperoleh. Beberapa orang menanam di pekarangannya namun tidak banyak hanya sekitar $1-5$ pohon saja. Tanaman masoi dipersepsikan oleh masyarakat sebagai tanaman yang susah tumbuh dan susah memperoleh bibitnya. Lebih dari itu perbanyakannya dari biji juga sulit daripada dari anakan, umumnya untuk memperoleh anakannya harus mencari di hutan. Pencarian anakan masoi hutan juga semakin sulit karena jumlah pohon yang terus menyusut. Persoalan jarak tempuh yang jauh juga mempersulit ketahanan anakan masoi untuk dapat hidup ketika dibudidayakan.

Di Teluk Wondama terdapat beberapa usaha pembibitan yang dikelola masyarakat setempat namun bibit masoi termasuk yang jarang tersedia. Untuk memperoleh bibit masoi harus dilakukan dengan cara pemesanan. Harga bibit masoi termasuk mahal jika dibandingkan bibit tanaman lain yang tersedia. Harga bibit masoi biasa dijual Rp 50.000/anakan.

Beberapa orang menganggap menanam masoi sulit dilakukan dan tidak menarik walaupun bernilai ekonomi tinggi. Hal ini dikarenakan :

1. Sulitnya memperoleh anakan masoi.

Untuk memperoleh anakan masoi, orang harus pergi ke hutan. Pencarian anakan masoi hampir sama dengan pencarian pohon masoi, karena anakan akan tumbuh di sekitar pohon induknya. Menurut pelaku usaha, beberapa sudah mencoba menyemai dari bibitnya namun tidak berhasil. Oleh karena itu harus mencari anakannya. Sulitnya memperoleh anakan masoi menyebabkan harga bibit masoi menjadi lebih mahal daripada bibit tanaman lain.

2. Perlu perlakuan yang cukup ekstra hati- hati dalam merawat tanaman masoi.

Kebiasaan masyarakat di Teluk Wondama mengusahakan tanamannya dengan cara peladangan berpindah, ada suatu masa ketika datang menanam kemudian meninggalkan tanamannya, untuk datang lagi memanen. Kebiasaan ini menyebabkan menanam masoi jadi hal yang tidak menarik, karena perlu perawatan yang kontinyu.

3. Tingkat kegagalan tanaman yang tinggi.

Menurut anggapan masyarakat tanaman masoi mempunyai hawa yang panas, sehingga perlu jarak tanam tertentu dengan tanaman lain, walaupun itu jenis tanaman masoi sendiri. Beberapa responden sudah pernah mencoba menanam namun banyak yang mati.

4. Memerlukan waktu yang lama untuk memperoleh hasilnya.

Sama seperti jenis tanaman hutan lainnya, sebagian masyarakat tidak tertarik untuk menanam masoi karena perolehan hasilnya masih harus menunggu lama.

5. Belum diperoleh teknik pemanenan yang ramah lingkungan dan lestari.

Teknik pemanenan yang dilakukan masyarakat masih dengan cara destruktif, yaitu dengan cara menebang pohon langsung, sehingga tidak ramah lingkungan dan mengancam kelestarian jenis ini.

Persepsi masyarakat terhadap tanaman masoi pada umumnya positif. Namun karena pengetahuan yang rendah terhadap teknik penanaman masoi menyebabkan sebagian besar masyarakat lokal kurang tertarik untuk membudidayakannya. Secara umum tanaman masoi cocok tumbuh di daerah 
ini dan masyarakat masih memiliki lahan yang luas yang bisa ditanami masoi.

\section{KESIMPULAN DAN SARAN}

\section{A. Kesimpulan}

Karakteristik sosial ekonomi pencari masoi adalah sebagian besar berjenis kelamin laki-laki, berusia produktif, tingkat pendidikan yang rendah, bermata pencaharian utama sebagai petani atau nelayan, status berkeluarga dengan tanggungan anggota keluarga antara $5-20$ orang dan tingkat pendapatan yang rendah. Berdasarkan tingkat pendapatan yang rendah dengan tanggungan anggota keluarga yang banyak, maka pencari masoi di Kabupaten Teluk Wondama dapat dikategorikan hidup dalam kemiskinan.

Gender terlihat pada peranan dan posisi perempuan di kelompok pencari masoi. Persepsi pencari masoi terhadap tanaman masoi pada umumnya positif, karena dianggap bernilai ekonomi tinggi dan kaya akan manfaat. Namun kurang tertarik untuk menanam walaupun secara umum masoi cocok ditanam di daerah tersebut dan masih luasnya lahan yang bisa ditanami dengan masoi. Hal tersebut dikarenakan 1) sulitnya memperoleh bibit masoi, 2) perlu ketekunan dan ketelitian dalam penanaman masoi, 3) tingkat kegagalan tanaman tinggi, 4) memerlukan waktu yang lama untuk memperoleh hasilnya, 5) belum diperoleh teknik pemanenan yang ramah lingkungan dan berasas kelestarian.

\section{B. Saran}

Peran multipihak diperlukan untuk meningkatkan produktivitas tananaman masoi, terutama dalam mensosialisasikan dan memfasilitasi pengembangan untuk peningkatan produktivitas tanaman masoi sebagai HHBK andalan Provinsi Papua Barat, terutama untuk mengubah mindset masyarakat dari pencari menjadi penanam/pembudidaya masoi. Selain itu diperlukan kebijakan khusus untuk melindungi dan mendukung produsen kulit masoi, terutama untuk memotivasi masyarakat menjadi petani masoi.

\section{UCAPAN TERIMA KASIH}

Terimakasih kepada Kepala Balai Litbang LHK Manokwari beserta staf atas dukungan pendanaan, Dr. Ir. Relawan Kuswandi, M.Sc selaku penanggung jawab penelitian Peningkatan Produktivitas Masoi yang telah memberikan kesempatan kepada penulis untuk melakukan penelitian, dan juga kepada Kepala Dinas Kehutanan Kabupaten Teluk Wondama Ir. Mulyono Herlambang, MM beserta staf dan masyarakat Kabupaten Teluk Wondama khususnya Kampung Senderawoi dan Kampung Rado atas dukungan moril yang diberikan.

\section{DAFTAR PUSTAKA}

Achmad, B., Purwanto, R. H., Sabarnudin, S., \& Sumadi. (2015). Tingkat Pendapatan dan Curahan Tenaga Kerja pada Hutan Rakyat Kabupaten Ciamis. Jurnal Ilmu Kehutanan, 9(2), 105116.

Adalina, Y. (2017). Pemanfaatan Hasil Hutan Bukan Kayu di Taman Nasional Gunung Halimun Salak oleh Masyarakat Kasepuhan Sinar Resmi, Jawa Barat Harvesting non-timber forest products in Mount Halimun Salak National Park by Kasepuhan Sinar Resmi Indigenous People, West Java YE. In Proseding Seminar Nasional Masyarakat Biodiversitas Indonesia (Vol. 3, pp. 75-80). 
https://doi.org/10.13057/psnmbi/m030 113

Ahdiah, I. (2013). Peran-peran Perempuan dalam Masyarakat. Jurnal Academica, 5(2), 1085-1092.

Anand, P., Hunter, G., Carter, I., Dowding, K., Guala, F., \& Hees, M. Van. (2009). The Development of Capability Indicators. Journal of Human Development and Capabilities, 10(1), 125-152. https://doi.org/10.1080/1464 9880802675366

Arifin, H., Fuady, I., \& Kuswarno, E. (2017). Analisis Faktor yang Mempengaruhi Persepsi Mahasiswa terhadap Keberadaan Perda Syariah di Kota Serang. Jurnal Penelitian Komonikasi Dan Opini Publik, 21(1), 88-101.

Asthika, K. (2010). Budaya Kemiskinan di Masyarakat: Tinjauan Kondisi Kemiskinan dan Kesadaran Budaya Miskin di Masyarakat. Jurnal Ilmiah Fakultas Ilmu Sosial Dan Ilmu Politik, I(1), 2010.

Beja, H., Mella, W., \& Soetendjo, I. (2015). Sistem Tebas Bakar dan Pengaruhnya Terhadap Komponen Fisik Kimia Tanah Serta Vegetasi pada Ladang dan Lahan Bera (Studi Kasus di Desa Pruda Kecamatan Waiblama Kabupaten Sikka Provinsi Nusa Tenggara Timur). Jurnal Keteknikan Pertanian, 3(2), 129-136. https://doi.org/10.19028/jtep.03.2.129136

Choi, H. J., McGarry, K., \& Schoeni, R. F. (2016). Consumption and the extended family. Economics Letters, 140, 3438.

https://doi.org/10.1016/j.econlet.2016.
01.002

Deda, A. J., \& Mofu, S. S. (2014). Masyarakat Hukum Adat dan Hak Ulayat di Provinsi Papua Barat sebagai Orang Asli Papua Ditinjau dari Sisi Adat dan Budaya Sebuah Kajian Etnografi Kekinian. Jurnal Administrasi Publik, 11(2).

Diarto, Hendrarto, B., \& Suryoko, S. (2012). Partisipasi Masyarakat dalam Pengelolaan Mangrove Tugurejo Kota Semarang. Jurnal Ilmu Lingkungan, 10(1), 1-7.

Diniyati, D., \& Awang, S. A. (2010). Kebijakan penentuan bentuk insentif pengembangan hutan rakyat di wilayah Gunung Sawal, Ciamis dengan metoda AHP. Jurnal Analisis Kebijakan Kehutanan, 7(2), 129-143.

Dwi, E. W. (2011). Peran Ganda Perempuan dan Kesetaraan Gender. Jurnal Muwazah, 3(1), 356-364.

Hartati, S. (2010). Pembagian Kerja Buruh Tani Berdasar Gender di Tawangmangu Karanganyar. Universitas Sebelas Maret Surakarta.

Helmi, A., \& A, S. (2012). Strategi Adaptasi Nelayan terhadap Perubahan Ekologis. Jurnal Makara, Sosial Humaniora, 16(1), 68-78.

Husaini, M. (2012). Karakteristik Sosial Ekonomi Rumah Tangga dan Tingkat Ketahanan Pangan Rumah Tangga Petani di Kabupaten Barito Kuala. Jurnal Agribisnis Perdesaan, 2(4), 320-332.

Intan, S. (2014). Kedudukan Perempuan dalam Domestik dan Publik Perspektif Jender. Jurnal Politik Profetik, 3(1), $1-16$. 
Kadir W, A. K., Awang, S. A., Purwanto, R. H., \& Poedjirahajoe, E. (2012). Analisis Kondisi Sosial dan Ekonomi Masyarakat Sekitar Taman Nasional Bantimurung Bulusaraung Provinsi Sulawesi Selatan. Jurnal Ilmu Manusia Dan Lingkungan, 19(1), 111.

Konro, M. (2002). Pengelolaan Usaha Tani Tanaman Pangan dan Upaya Perbaikannya di Papua. Jurnal Litbang Pertanian, 2(21), 140-147.

Kurniawan, A. (2015). Analisis Faktor-faktor yang Mempengaruhi Upah Buruh Petik Sawit PT. Sinergi Perkebunan Nusantara di Morowali Sulawesi Tengah. Universitas Hasanuddin Makassar.

Kurniawan, A., \& Rudiansjah, T. (2016). Kajian Mengenai Perubahan Afiliasi pada Sistem Organisasi Sosial Masyarakat Lematang. Jurnal Antropologi, 18(2), 89-103.

Kuswandi, R. (2015). Mengenal Masoi (Cryptocarya spp). Manokwari.

Mahmud, I. (2014). Komoditas dan Dinamika Perdagangan di Papua. Berkala Arkeologi, 34(2), 183-198.

Maulana, I. (2013). Analisis Pengaruh Keterampilan, Jumlah Tanggungan Keluarga, Pendapatan dan Pendidikan Terhadap Keluarga Miskin di Sumbergondo, Glenmore, Banyuwangi. Universitas Jember.

Nurdina, I. F., Kustanti, A., \& Hilmanto, R. (2015). Motivasi Petani dalam Mengelola Hutan Rakyat di Desa Sukoharjo, Kecamatan Sukoharjo Kabupaten Pringsewu. Jurnal Sylva Lestari, 3(3), 51-62.
Nurlian, \& Daulay, H. (2008). Kesetaraan Gender dalam Pembagian Kerja pada Keluarga Petani Ladang di Cot Rambang, NAD. Jurnal Harmoni Sosial, II(2), 76-82.

Puspitawati, H. (2012). Gender dan Keluarga: Konsep dan Realita. Bogor: PT IPB Press.

Rehalat, A. (2014). Model Pembelajaran Pemrosesan Informasi. Jurnal Pendidikan Ilmu Sosial, 23(2), 1-10.

Rosaldo, M., \& Lapere, L. (1974). Woman, Culture dan Society. Stanford: Stanford University Press.

Rostiwati, T., \& Martono, K. (2014). Buku Panduan Kehutanan. Bogor: Badan Litbang Kehutanan.

Saidah. (2013). Sistem Pembagian Kerja Berdasarkan Jenis Kelamin (Analisis Gender terhadap Tenaga Kerja Perkebunan Sawit PT. Muaratoyu Subur Lestari di Kabupaten Paser). eJournal Sosiologi Konsentrasi, 1(1), 1-12. Retrieved from http://ejournal. sos.fisip-unmul.ac.id/ site/wp-content/ uploads/2013/10/ jurnal saidah NEW(10-27-13-09-55-07). pdf.

Sanudin, \& Fauziyah, E. (2015). Karakteristik hutan rakyat berdasarkan orientasi pengelolaannya: Studi kasus di Desa Sukamaju, Ciamis dan Desa Kiarajangkung, Tasikmalaya, Jawa Barat. In Proseding Seminar Masyarakat Biodiversity Indonesia (Vol. 1, pp. 696-701). https://doi.org/ 10.13057/psnmbi/m010402

Statistik, B. P. (2008). Analisis Perkembangan Statistik Ketenagakerjaan (Laporan Sosial Indonesia 2007). Jakarta: Badan Pusat Statistik. 
Supratman. (2008). Analisis Struktur Wilayah dan Kinerja Pengelolaan Hutan Di Kabupaten Maros Sulawesi Selatan. Jurnal Hutan Dan Kemasyarakatan, 2(2), 222-229.

Suryawati, C. (2005). Memahami Kemiskinan Secara Multidimensional. Manajemen Dan Kebijakan Pembangunan, 8(3), 121-129.

Susanto, N. H. (2015). Tantangan Mewujudkan Kesetaraan Gender dalam Budaya Patriarki. Jurnal Muwazah, 7(2), 120-130.

Syah, R. F. (2017). Analisa Kebijakan Sektor Lingkungan:

Permasalahan Implementasi Kebijakan Pengelolaan Kawasan Hutan di Indonesia. Journal of Governance, 2(1), 2-17.
Talaohu, M. (2013). Perladangan Berpindah: Antara Masalah Sosial dan Masalah Lingkungan. Jurnal Populis, 7(1), 5963.

Todaro, M. (2008). Pembangunan Ekonomi di Dunia Ketiga. Jakarta: Penerbit Airlangga.

Wasak, M. (2012). Keadaan Sosial Ekonomi Masyarakat Nelayan di Desa Kinabuhutan, Likupang Barat, Minahasa Utara, Sulawesi Utara. Pacific Journal, 1(7), 1339-1342.

Wondama, B. T. (2013). Indikator Kesejahteraan Rakyat 2013. Teluk Wondama: BPS Teluk Wondama.

Zaduqisti, E. (2009). Stereotipe Peran Gender dalam Pendidikan Anak. Jurnal Muwazah, 1(1), 73-82. 